\title{
Pengaruh Model Pembelajaran Kooperatif Co-op Co-op Terhadap Keterampilan Menulis Teks Eksposisi pada Siswa Kelas VII B SMP Negeri 1 Singkawang
}

\section{Lili Yanti ${ }^{1}$, Zulfahita ${ }^{2}$}

Program Studi Pendidikan Bahasa dan Sastra Indonesia, STKIP Singkawang Email: liliyantiana18@gmail.com, Email: zulfahita@yahoo.co.id

\author{
Keywords : Keterampilan \\ Menulis, Model \\ Pembelajaran Kooperatif $\mathrm{Co}$ - \\ op Co-op, Teks Eksposisi
}

\begin{abstract}
Penelitian ini bertujuan untuk mengetahui pengaruh model pembelajaran kooperatif Co-op Co-op terhadap keterampilan menulis teks eksposisi siswa kelas VII B SMP Negeri 1 Singkawang. Penelitian ini merupakan penelitian kuantitatif dengan rancangan One Group Pre-test Post-test Design. Populasi dalam penelitian ini adalah siswa kelas VII SMP Negeri 1 Singkawang. Sampel penelitian dengan teknik simpel random sampling, yaitu kelas VII B SMP Negeri 1 Singkawang. Alat pengumpul data yang digunakan berupa lembar tes. Hasil validasi soal tes dalam penelitian ini berkategori tinggi. Reliabilitas instrumen tes diperoleh koefisien reliabilitas sebesar 0,786 dengan kategori cukup dan layak digunakan pada penelitian. Hasil rata-rata nilai pre-test dan post-test masingmasing sebesar 64,24 dan 86,58. Analisis Paired-Sampel T-Test dengan taraf signifikansi 0,05, diperoleh nilai sig $(2$ tailed $)=$ 0,000, karena sig (2 tailed) < 0,05 maka ditemukan model pembelajaran kooperatif Co-op Co-op memiliki pengaruh yang signifikan terhadap keterampilan menulis teks eksposisi pada siswa kelas VII B SMP Negeri 1 Singkawang. Model pembelajaran kooperatif Co-op Co-op sebaiknya diterapkan pada materi pelajaran bahasa Indonesia yang lain dan di sekolah lainnya sebagai pembanding hasil temuan.
\end{abstract}




\section{PENDAHULUAN}

Menulis pada dasarnya telah diajarkan dan didapat siswa sejak masih di bangku Sekolah Dasar (SD). Menulis merupakan suatu kegiatan yang sifatnya berkelanjutan, sehingga pembelajarannya juga perlu dilakukan secara berkesinambungan. Tujuan pembelajaran menulis adalah agar siswa dapat berpikir kritis, memiliki keterampilan dalam mengungkapkan gagasan, ide, pendapat, dan pengetahuan secara sistematis dan terpadu agar dapat mudah dipahami maknanya oleh pembaca.

Berkaitan dengan pembelajaran di sekolah, materi teks eksposisi merupakan satu di antara materi yang harus dicapai oleh siswa khususnya kelas VII kurikulum 2013. Pada teks eksposisi yang disampaikan kepada pembaca adalah informasi yang berupa fakta dan tidak bertujuan untuk memengaruhi pembaca (Suparno \& Mohamad, 2007: 1.12). Oleh karena itu, siswa dituntut untuk mampu menyajikan, menerangkan, dan menginformasikan suatu hal sesuai fakta.

Namun pada kenyataannya, ditemukan rendahnya kemampuan menulis siswa dalam pembelajaran. Hal ini karena menulis tidak sekadar aktivitas fisik, tetapi juga memerlukan penalaran dan pengetahuan yang luas (Saddhono \& Slamet, 2012: 96). Selain itu, berpikir kritis memerlukan latihanlatihan yang berkelanjutan, berpola secara sistematis, dan terus-menerus.

Berdasarkan hasil wawancara dengan satu di antara guru mata pelajaran bahasa Indonesia SMP Negeri 1 Singkawang bahwa keterampilan menulis siswa masih rendah, sehingga masih banyak siswa yang nilainya belum mencapai Kriteria Ketuntasan Minimal (KKM). Nilai KKM yang harus dicapai oleh siswa pada mata pelajaran bahasa Indonesia kelas VII di SMP Negeri 1 Singkawang adalah 75.

Penyebab minimnya keterampilan siswa dalam menulis karena siswa kurang aktif dalam mencari informasi dan hanya mengharapkan penjelasan guru. Hal tersebut mengakibatkan pengetahuan siswa tidak luas, kosakata yang dimiliki siswa rendah, sulitnya siswa dalam mengembangkan ide-ide, serta kurangnya minat dan motivasi siswa untuk menulis.

Selain itu, guru masih mengalami kesulitan dalam menentukan model pembelajaran yang tepat, sehingga pembelajaran yang inovatif dan kreatif menjadi solusi untuk menghadapi berbagai hambatan yang muncul. Terutama dalam pemilihan model pembelajaran haruslah tepat dan sesuai dengan karakteristik siswa, memerhatikan kondisi siswa, sifat materi bahan ajar, fasilitas/media yang tersedia, dan kondisi guru itu sendiri, sehingga menunjang terciptanya suasana kegiatan belajar yang kondusif dan menarik bagi siswa.

Berdasarkan hal tersebut, dibutuhkan suatu model pembelajaran yang mampu mengoptimalkan keterampilan menulis siswa dalam pembelajaran. Pada penelitian ini diterapkan model pembelajaran kooperatif Co-op Co-op pada pembelajaran menulis teks eksposisi. Model pembelajaran kooperatif tipe Co-op Co-op tidak sama dengan sekadar belajar dalam kelompok (Lisnawati, 2012: 1). Pada model pembelajaran ini, siswa juga dituntut untuk belajar mandiri dalam penyelesaian tugas. Model kooperatif Co-op Co-op ini juga dapat meningkatkan kemampuan menulis siswa, serta meningkatkan kemampuan komunikasi siswa. Model kooperatif Co-op Co-op diharapkan dapat meningkatkan keterampilan menulis siswa pada teks eksposisi.

Keterampilan menulis pada penelitian ini menitikberatkan pada beberapa aspek penilaian yaitu isi, organisasi, kosakata, penggunaan bahasa, dan mekanik. Isi menyangkut informasi yang disampaikan relevan dan tuntas. Organisasi menyangkut gagasan yang diungkapkan jelas, padat, dan urutannya logis serta sesuai dengan struktur teks eksposisi. Kosakata menyangkut pemilihan dan penggunaan kata yang tepat. Penggunaan bahasa menyangkut pola kalimat dan keefektifan kalimat. Mekanik menyangkut penulisan kata dan ejaan sesuai dengan Ejaan Yang Disempurnakan (EYD). 


\section{KAJIAN TEORI}

Pembelajaran kooperatif (cooperative learning) merupakan suatu teknik pembelajaran yang mengeksplorasi keaktifan siswa untuk berinteraksi dalam satu kelompok kecil (Nurulhayati, 2002: 25). Dalam sistem belajar yang kooperatif, siswa belajar bekerja sama dengan anggota lainnya. Dalam model ini siswa memiliki dua tanggung jawab, yaitu mereka belajar untuk dirinya sendiri dan membantu sesama anggota kelompok untuk belajar. Siswa belajar bersama dalam sebuah kelompok kecil dan mereka dapat melakukannya seorang diri.

Model pembelajaran kooperatif Co-op Co-op merupakan satu di antara berbagai model pembelajaran cooperative learning. Model pembelajaran ini menempatkan tim dalam koperasi antara satu dengan lainnya untuk mempelajari sebuah topik di kelas. Co-op Co-op memberi kesempatan pada siswa untuk bekerja sama dalam kelompok-kelompok kecil, bertujuan untuk meningkatkan pemahaman tentang diri siswa sendiri dan dunia, dan selanjutnya memberikan siswa kesempatan untuk saling berbagi pemahaman baru itu dengan teman-teman sekelasnya (Slavin, 2010: 229).

Pembelajaran kooperatif group investigation bentuk Co-op Co-op adalah teknik pembelajaran kooperatif yang dapat mendorong anggota kelompok untuk memperoleh konsep secara mendalam melalui pemberian peran pada siswa. Model pembelajaran ini dikembangkan oleh Spencer Kagan (Rifa'i, 2013: 4). Kelompok investigasi bentuk koordinir-koordinir (group investigation bentuk Co-op Co-op) memberikan kesempatan kepada kelompok untuk membagikan hasil dan informasi dengan kelompok lain (Lie, 2008: 61).

Secara lebih rinci, sintaks model pembelajaran kooperatif Co-op Co-op (Slavin, 2010: 229-236) dengan dimodifikasi, yaitu sebagai berikut.

1. Diskusi kelas terpusat pada siswa. Pada awal memulai pembelajaran Co-op Co-op, guru menampilkan sebuah gambar dan berdiskusi bersama siswa untuk menarik minat siswa mengikuti proses pembelajaran.

2. Menyeleksi tim pembelajaran siswa dan pembentukan kelompok. Guru membagi siswa secara berkelompok yang heterogen. Setiap kelompok terdiri dari empat sampai lima siswa. Masingmasing individu mengambil satu kertas yang berisikan nama kelompok.

3. Seleksi topik tim. Masing-masing anggota kelompok mengambil sebuah kertas yang berisikan tema dan karangan eksposisi untuk didiskusikan pada kelompoknya. Setiap karangan memiliki lima paragraf yang disusun secara acak.

4. Pemilihan topik kecil. Pada langkah ini adanya komunikasi antar anggota kelompok. Tiap kelompok membagi topik utama menjadi topik mini untuk pembagian tugas di antara anggota kelompok. Anggota kelompok didorong untuk saling berbagi referensi dan bahan pelajaran. Setiap kelompok membagi paragraf tersebut, untuk dikerjakan secara individual. Masing-masing individu mendapat satu paragraf.

5. Persiapan topik kecil. Setelah para siswa membagi topik tim menjadi topik-topik kecil, siswa akan bekerja secara individual. Setiap siswa mengetahui tanggung jawabnya terhadap topik kecilnya, dan untuk menyelesaikan topik kecil tersebut tergantung padanya untuk menemukan aspek-aspek penting dari usaha yang dilakukan tim. Persiapan topik kecil bisa saja melibatkan penelitian kepustakaan, pengumpulan data melalui wawancara atau eksperimen, menciptakan proyek individual, atau sebuah kegiatan ekspresif seperti menulis atau melukis. Siswa secara individu memperbaiki dan menulis paragraf yang menjadi tugasnya berdasarkan soal yang telah diberikan dengan penuh tanggung jawab, dan dapat menggunakan berbagai referensi.

6. Presentasi kelompok kecil. Setelah para siswa menyelesaikan kerja individual, setiap siswa dalam kelompok mempresentasikan topik kecil kepada teman satu timnya. Hal ini bertujuan untuk mengoreksi bersama-sama hasil kerja setiap individu dan diperbaiki jika terjadi kekeliruan.

7. Persiapan presentasi tim. Para siswa didorong untuk mengombinasikan atau menyatukan semua topik kecil dalam presentasi tim. Paragraf yang telah dikerjakan, kemudian digabungkan dan disusun menjadi suatu paragraf yang utuh, dan sesuai dengan struktur teks eksposisi.

8. Presentasi tim. Tiap kelompok mempresentasikan hasil diskusinya pada topik kelompok. Semua anggota kelompok bertanggung jawab terhadap presentasi kelompok. 
9. Evaluasi. Evaluasi dilakukan pada tiga tingkatan: (1) pada saat presentasi tim dievaluasi oleh kelas; (2) kontribusi individual terhadap usaha tim dievaluasi teman satu tim; (3) pengulangan kembali materi atau presentasi topik kecil oleh tiap siswa dievaluasi oleh sesama siswa.

Dengan menguasai langkah-langkah dalam pembelajaran kooperatif Co-op Co-op ini, maka tercapailah pembelajaran yang lebih efektif dan tujuan pembelajaran juga tercapai. Penerapan model pembelajaran ini tidak terlepas dari arahan guru dalam proses pembelajaran agar siswa lebih teratur dan terarah saat melaksanakan tugas dalam berdiskusi.

Pada hakikatnya keterampilan menulis adalah kemampuan seseorang dalam menuangkan ide ke dalam bahasa tulis melalui rangkaian kalimat-kalimat yang utuh, lengkap, dan jelas sehingga tujuan mengomunikasikan kepada pembaca dapat tercapai (Byrne, 1979: 3). Keterampilan menulis menuntut kemampuan menggunakan pola-pola bahasa secara tertulis untuk mengungkapkan suatu gagasan atau pesan.

Keterampilan menulis teks eksposisi pada penelitian yang dilakukan ini, yaitu kemampuan siswa dalam menyajikan informasi yang lengkap dan relevan, pengorganisasian isi yang sistematis, pemilihan kosakata dan penggunaan bahasa yang tepat, serta penggunaan ejaan dan tanda baca yang sesuai dengan EYD.

Untuk menjadi terampil dalam menulis, maka perlu dipahami dan dipelajari tahapan-tahapan dalam menulis. Ada lima tahap atau kegiatan yang dilakukan pada proses penulisan, yaitu persiapan penulisan (rehearsing), pembuatan draft (drafting), perevisian (revising), pengeditan (editing), dan pemublikasian (publishing/sharing) (Tompkins, 1990: 73).

Pada karangan eksposisi masalah yang dikomunikasikan terutama adalah informasi. Hal tersebut dapat berupa data faktual, suatu analisis atau suatu penafsiran yang objektif terhadap seperangkat fakta, dan dapat juga berupa fakta tentang seseorang yang berpegang teguh pada suatu pendirian yang khusus (Suparno \& Mohamad, 2007: 5.6). Tujuan karangan eksposisi yaitu memberi penjelasan atau keterangan. Selain itu, eksposisi juga bertujuan mengembangkan gagasan penulis. Dalam paparan tersebut dapat disertakan gambar, denah, dan angka-angka (Darmawati, dkk., 2014: 58).

\section{METODE PENELITIAN}

Metode yang digunakan dalam penelitian ini adalah metode eksperimen dengan jenis penelitian kuantitatif. Bentuk penelitian berupa pre-experimental design dengan rancangan yang digunakan adalah "One Group Pre-test Post-test Design". Desain ini ditunjukkan pada Gambar 1 sebagai berikut.

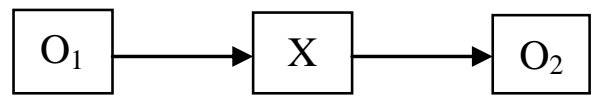

Gambar 1 Skema One Group Pre-test Post-test Design

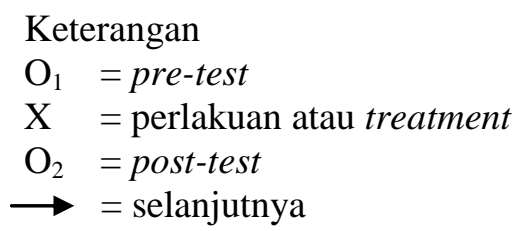

Populasi dalam penelitian ini adalah siswa kelas VII SMP Negeri 1 Singkawang, sedangkan sampel penelitian adalah siswa kelas VII B dengan teknik pengambilan sampel berupa simple random sampling. Instrumen pengumpulan data berupa lembar tes sebanyak tiga soal esai dengan penilaian berlandaskan penilaian Nurgiyantoro (2010: 441-442). Aspek yang dinilai dalam kategori ini, yaitu isi karangan, organisasi isi, kosakata, penggunaan bahasa, dan mekanik. 
Uji validitas yang digunakan dalam penelitian ini adalah uji validitas isi. Validitas isi ini diuji oleh orang yang ahli dalam bidang yang bersangkutan yaitu satu orang dosen bidang studi Pendidikan Bahasa dan Sastra Indonesia STKIP Singkawang, dan satu orang guru bahasa Indonesia SMP. Berdasarkan hasil validasi lembar tes dari kedua validator diperoleh total rata-rata sebesar empat. Hal ini menunjukkan bahwa tingkat validasi yang dicapai pada lembar soal tes dalam penelitian ini berkategori tinggi. Selanjutnya, soal tes tersebut diuji reliabilitasnya di sekolah yang berbeda, tetapi memiliki karakteristik yang sama dengan tempat dilaksanakannya penelitian.

Pada soal tes perlu ditentukan nilai reliabilitasnya untuk menyatakan reliabel atau tidaknya soal tes tersebut. Uji coba tes dilaksanakan di SMP Negeri 3 Singkawang. Alasan memilih sekolah ini sebagai lokasi uji coba soal tes adalah karena akreditasi yang sama, kurikulum yang digunakan sama, lokasi sekolah ini cukup dekat dengan sekolah tempat dilaksanakan penelitian, dan siswa di SMP Negeri 3 Singkawang memiliki karakteristik yang sama dengan siswa di SMP Negeri 1 Singkawang. Setelah soal tes diujicobakan, tahap selanjutnya adalah menghitung reliabilitas tes. Uji coba soal hanya diikuti oleh 35 siswa. Setelah diujicobakan dan hasilnya dianalisis diperoleh koefisien reliabilitas sebesar 0,786. Hal ini menunjukkan bahwa reliabilitas instrumen tes termasuk kategori cukup.

Analisis data pada penelitian ini menjelaskan pengaruh model pembelajaran kooperatif Co-op Co-op terhadap keterampilan menulis teks eksposisi pada siswa kelas VII B SMP Negeri 1 Singkawang. Tes yang digunakan untuk mengetahui kemampuan siswa dalam menulis teks eksposisi, yaitu tes tertulis. Penskoran hasil tes ini didasarkan pada pedoman penilaian menulis teks eksposisi yang ditampilkan pada Tabel 1, kemudian dicari rata-rata hitungnya (mean). Rumus untuk mencari rata-rata hitung adalah sebagai berikut.

$$
\mathrm{M}_{\mathrm{X}}=\frac{\sum \mathrm{X}}{\mathrm{N}}
$$

Keterangan:

$\mathrm{M}_{\mathrm{X}}=$ Nilai rata-rata hitung (mean)

$\Sigma \mathrm{X}=$ Jumlah dari hasil skor yang diperoleh

$\mathrm{N}$ = Banyaknya data

(Sudijono, 2014: 82-83)

Teknik analisis data dalam penelitian kuantitatif menggunakan statistik, yaitu statistik parametris dengan rumus Paired-Sampel T-Test melalui program SPSS 15 dalam analisis datanya. Namun, sebelum menggunakan statistik parametris terlebih dahulu data dianalisis dengan rumus One-Sample Kolmogorov-Smirnov Test melalui program SPSS 15. Hal ini bertujuan untuk mengetahui data berdistribusi normal atau tidak normal. Data yang didapat dalam penelitian ini berdistribusi normal, selanjutnya data dianalisis dengan statistik parametris.

\section{HASIL PENELITIAN}

Dalam penelitian ini digunakan suatu instrumen yang berupa RPP dan tes. Suatu instrumen harus memiliki syarat, yaitu valid dan reliabel. Instrumen divalidasi oleh dua orang validator, kemudian instrumen tersebut diperbaiki. Berdasarkan hasil validasi lembar tes diperoleh rata-rata hasil validasi dari kedua validator sebesar empat. Hal ini menunjukkan bahwa tingkat validasi yang dicapai pada lembar soal tes dalam penelitian ini berkategori tinggi. Selanjutnya, soal tes tersebut diuji reliabilitasnya, dan hasil uji coba diperoleh koefisien reliabilitas sebesar 0,786. Hal ini menunjukkan bahwa reliabilitas instrumen tes termasuk kategori cukup.

Hasil penelitian ini membahas tentang hasil analisis data yang meliputi analisis data pre-test dan analisis data post-test. Data penelitian diperoleh dari hasil tes menulis teks eksposisi yang dilakukan oleh siswa kelas VII B SMP Negeri 1 Singkawang yang berjumlah 35 siswa dan hanya diikuti oleh 33 siswa. Tes yang digunakan untuk mengetahui keterampilan siswa dalam menulis teks eksposisi, yaitu tes tertulis. Penskoran hasil tes ini berdasarkan pada pedoman penilaian yang telah dibuat. 
Pelaksanaan tes dalam penelitian ini dilakukan sebanyak dua kali, yaitu tes yang dilaksanakan sebelum (pre-test) dan sesudah (post-test) perlakuan.

Data dari hasil pre-test dan post-test yang diperoleh siswa selanjutnya dianalisis melalui perhitungan statistik. Langkah pertama yang dilakukan yaitu skor yang diperoleh disusun dalam tabel kemudian dicari rata-rata hitung (mean) dengan menggunakan bantuan program Microsoft Office Excel 2007. Hasil rata-rata pre-test adalah sebesar 64,24 , dan hasil rata-rata post-test diperoleh sebesar 86,58. Berdasarkan kategori nilai ditemukan bahwa keterampilan menulis teks eksposisi siswa sebelum digunakan model pembelajaran kooperatif Co-op Co-op memiliki kategori kurang, sedangkan sesudah digunakan model pembelajaran kooperatif Co-op Co-op keterampilan menulis teks eksposisi siswa memiliki kategori baik.

Setelah data diperoleh, maka selanjutnya data tersebut dianalisis menggunakan uji statistik. Langkah pertama dalam menganalisis data, yaitu menghitung uji normalitas data menggunakan One-Sample Kolmogorov-Smirnov Test dengan bantuan program SPSS 15.

a) Menguji Normalitas

Menguji normalitas ini bertujuan untuk mengetahui apakah data yang diperoleh berdistribusi normal atau berdistribusi tidak normal. Hal demikian bertujuan untuk menentukan apakah digunakan statistik parametris atau nonparametris. Untuk menguji normalitas data pre-test dan post-test digunakan bantuan program SPSS 15. Adapun uji normalitas data pre-test, ditampilkan pada Tabel 1 sebagai berikut.

Tabel 1. One-Sample Kolmogorov-Smirnov Test (Pre-test)

\begin{tabular}{lll}
\hline & & Pre-test \\
\hline$N$ & Mean & 33 \\
Normal Parameters $(a, b)$ & Std. Deviation & 64,2424 \\
& Absolute & 7,85426 \\
Most Extreme Differences & Positive &, 189 \\
& Negative &, 189 \\
& &,- 134 \\
Kolmogorov-Smirnov $Z$ & & 1,085 \\
Asymp. Sig. (2-tailed) & &, 190 \\
\hline
\end{tabular}

a Test distribution is Normal.

$b$ Calculated from data.

Dari hasil uji satu sampel tersebut menunjukkan $N=33$ yang berarti jumlah sampel yang diambil sebanyak 33 orang. Dari Asymp. Sig. (2-tailed) sebesar 0,190, jadi probabilitas 0,190 > 0,05. Dengan demikian, disimpulkan bahwa hasil pre-test berdistribusi normal. Selanjutnya uji normalitas data hasil post-test, ditampilkan pada Tabel 2 sebagai berikut.

\begin{tabular}{lll}
\multicolumn{2}{c}{ Tabel 2 One-Sample Kolmogorov-Smirnov Test (Post-test) } \\
\hline$N$ & & Post-test \\
\hline$N$ & Mean & 33 \\
Normal Parameters $(a, b)$ & Std. Deviation & 86,5758 \\
& Absolute &, 196433 \\
Most Extreme Differences & Positive &, 148 \\
& Negative &,- 192 \\
Kolmogorov-Smirnov $Z$ & & 1,102 \\
Asymp. Sig. (2-tailed) & &, 176 \\
\hline
\end{tabular}

a Test distribution is Normal.

$b$ Calculated from data. 
Pada Tabel 2, Asymp. Sig. (2-tailed) sebesar 0,176, probabilitas 0,176>0,05. Dengan demikian data hasil post-test berdistribusi normal.

Berdasarkan hasil perhitungan kedua data, maka dapat dilihat bahwa data pre-test dan post-test berdistribusi normal. Dengan demikian, analisis data digunakan rumus statistik parametris dengan rumus Paired-Sampel T-Test. Untuk melakukan perhitungan digunakan bantuan program SPSS 15.

b) Uji Statistik Parametris dengan Paired-Sampel T-Test

Paired-Samples T-Test digunakan untuk melakukan uji beda dua sampel berpasangan (Hidayat \& Istiadah, 2011: 88). Sampel berpasangan merupakan subjek yang sama namun mengalami perlakuan yang berbeda, yaitu tes awal (pre-test) tanpa perlakuan dan tes akhir (post-test) dengan perlakuan. Adapun perhitungan rumus Paired-Sampel T-Test, ditampilkan pada Tabel 3, Tabel 4, dan Tabel 5 sebagai berikut.

Tabel 3. Paired Samples Statistics

\begin{tabular}{|c|c|c|c|c|c|}
\hline & & Mean & $N$ & Std. Deviation & Std. Error Mean \\
\hline \multirow[t]{2}{*}{ Pair 1} & Pre-test & 64,2424 & 33 & 7,85426 & 1,36725 \\
\hline & Post-test & 86,5758 & 33 & 6,96433 & 1,21233 \\
\hline
\end{tabular}

Tabel 4. Paired Samples Correlations

\begin{tabular}{lrrrr}
\hline & & $N$ & \multicolumn{1}{c}{ Correlation } & \multicolumn{1}{c}{ Sig. } \\
\cline { 3 - 5 } Pair 1 & Pre-test \& Post-test & 33 &, 180 &, 317 \\
\hline
\end{tabular}

Tabel 5. Paired Sampel Test

Paired Difference

\begin{tabular}{|c|c|c|c|c|c|c|c|c|}
\hline & \multirow[t]{2}{*}{ Mean } & \multirow{2}{*}{$\begin{array}{c}\text { Std. } \\
\text { Deviation }\end{array}$} & \multirow{2}{*}{$\begin{array}{c}\text { Std. Error } \\
\text { Mean }\end{array}$} & \multicolumn{2}{|c|}{$\begin{array}{l}\text { 95\% Confidence Interval } \\
\text { of the Difference }\end{array}$} & \multirow[t]{2}{*}{$t$} & \multirow[t]{2}{*}{$d f$} & \multirow{2}{*}{$\begin{array}{c}\text { Sig. (2- } \\
\text { tailed) }\end{array}$} \\
\hline & & & & Lower & Upper & & & \\
\hline $\begin{array}{l}\text { Pair } 1 \text { Pre- } \\
\text { test Post-test }\end{array}$ & $-22,33333$ & $-9,51534$ & $-1,65641$ & $-25,70733$ & $-18,95934$ & $-13,483$ & 32 & 0,000 \\
\hline
\end{tabular}

Pada Tabel 4, menunjukkan ringkasan dari rata-rata dan standar deviasi dari kedua perbandingan. Sebelum digunakan model pembelajaran kooperatif Co-op Co-op nilai rata-rata sebesar 64,24, sedangkan sesudah digunakan model pembelajaran kooperatif Co-op Co-op rata-rata yang diperoleh dari 33 siswa adalah sebesar 86,58 (hasil pembulatan). Tabel 5 menunjukkan hasil korelasi antara dua tes yang diberikan (pre-test dan post-test). Korelasi ditunjukkan pada angka 0,180.

Nilai $t_{\text {hitung }}$ sebesar $-13,483$ dengan sig. (2 tailed) 0,000. Jika probabilitas $>0,05$ maka tidak terdapat pengaruh yang signifikan antara sebelum dan sesudah digunakan model pembelajaran kooperatif $\mathrm{Co}$ op Co-op terhadap keterampilan menulis teks eksposisi siswa kelas VII B SMP Negeri 1 Singkawang. Tetapi jika probabilitas $<0,05$ maka terdapat pengaruh yang signifikan antara sebelum dan sesudah digunakan model pembelajaran kooperatif Co-op Co-op terhadap keterampilan menulis teks eksposisi siswa kelas VII B SMP Negeri 1 Singkawang. Tabel 6 menunjukkan bahwa probabilitas < 0,05, artinya terdapat pengaruh yang signifikan antara sebelum dan sesudah digunakan model pembelajaran kooperatif Co-op Co-op terhadap keterampilan menulis teks eksposisi siswa kelas VII B SMP Negeri 1 Singkawang. 
Penelitian ini bertujuan untuk mengetahui pengaruh model pembelajaran kooperatif Co-op Co-op terhadap keterampilan siswa dalam menulis teks eksposisi. Hasil penelitian ini menunjukkan bahwa terdapat perbedaan hasil tes awal kemampuan menulis teks eksposisi sebelum diberikan perlakuan, dengan tes akhir sesudah diberikan perlakukan melalui model pembelajaran kooperatif Co-op Co-op. Perbedaan tersebut berdasarkan perhitungan nilai rata-rata (mean), bahwa nilai rata-rata pre-test adalah sebesar 64,24, dan nilai rata-rata post-test diperoleh sebesar 86,58. Hal ini menunjukkan bahwa terdapat pengaruh model pembelajaran kooperatif Co-op Co-op terhadap keterampilan menulis teks eksposisi siswa kelas VII B SMP Negeri 1 Singkawang.

Hasil-hasil penelitian sebelumnya juga telah membuktikan bahwa model pembelajaran kooperatif $\mathrm{Co}$ op Co-op sangat menentukan keberhasilan dalam pembelajaran. Seperti penelitian yang dilakukan oleh Noorbaiti (2013: 13), penerapan model pembelajaran Co-op Co-op dapat meningkatkan kemampuan menulis puisi. Hal ini disebabkan karena model pembelajaran ini mempunyai kelebihankelebihan. Kelebihan model pembelajaran ini adalah dapat membantu siswa menumbuhkan ide-ide dan rasa percaya diri, dan dapat membuat siswa lebih aktif dalam pembelajaran.

Berdasarkan hasil analisis data yang telah dilakukan, diperoleh nilai rata-rata pre-test sebesar 64,24 dikategorikan kurang, dan nilai rata-rata post-test sebesar 86,58 dikategorikan baik. Pada uji statistik parametris ditemukan bahwa probabilitas kurang dari 0,05 , maka Ho ditolak. Hal ini berarti penerapan model pembelajaran kooperatif Co-op Co-op memiliki pengaruh yang signifikan terhadap keterampilan menulis teks eksposisi pada siswa kelas VII B SMP Negeri 1 Singkawang.

\section{SIMPULAN}

Berdasarkan hasil penelitian dan pembahasan yang telah dipaparkan pada bab IV dapat disimpulkan bahwa terdapat pengaruh model pembelajaran kooperatif Co-op Co-op terhadap keterampilan menulis teks eksposisi pada siswa kelas VII B SMP Negeri 1 Singkawang. Keterampilan menulis teks eksposisi siswa kelas VII B sebelum menggunakan model pembelajaran kooperatif Co-op Co-op di SMP Negeri 1 Singkawang berkategori kurang, sedangkan sesudah menggunakan model pembelajaran kooperatif Co-op Co-op di SMP Negeri 1 Singkawang berkategori baik. Model pembelajaran kooperatif Co-op Co-op memiliki pengaruh yang signifikan terhadap keterampilan menulis teks eksposisi siswa kelas VII B SMP Negeri 1 Singkawang. Model pembelajaran kooperatif Co-op Co-op sebaiknya diterapkan dalam proses pembelajaran yang dilaksanakan di sekolah, sebab model pembelajaran kooperatif Co-op Co-op dapat meningkatkan keterampilan dan hasil belajar siswa.

\section{DAFTAR PUSTAKA}

Byrne, D. (1979). Teaching Eriting Skill. London: Longman.

Darmawati, U., Maya, G.S., \& Y. Budi A. (2014). Bahasa Indonesia: SMP/MTs Kelas VII Semester 1. Jakarta: Intan Pariwara.

Hidayat, T., \& N. Istiadah (2011). Panduan Lengkap Menguasai SPSS 19 Untuk Mengolah Data Statistik Penelitian. Jakatara: Mediakita.

Lie, A. (2008). Cooperative Learning: Mempraktikan Cooperative Learning di Ruang-ruang Kelas. Jakarta: Grasindo

Lisnawati, L. (2012). Model Pembelajaran Kooperatif (Kerjasama) dalam Menulis Kreatif Naskah Drama pada Siswa Kelas VIII SMP Negeri 2 Singajaya Kabupaten Garut Tahun Ajaran 2011/2012. Jurnal Program Studi PBS Indonesia STKIP Siliwangi Bandung.

http://publikasi.stkipsiliwangi.ac.id/files/2013/01/makalah-Lina-lisnawati.pdf (Diakses 25 November 2014).

Noorbaiti (2013). Peningkatan Kemampuan Menulis Puisi dengan Metode Pembelajaran Kooperatif Co-op Co-op Pada Siswa Kelas VIII. Jurnal, FKIP, Vol 3, No 6, 2014. Pontianak: UNTAN. http://jurnal.untan.ac.id/index.php/jpdpb/article/view/5470/5960 (Diakses 25 November 2014). 
Nurulhayati, S. (2002). Pembelajaran Kooperatif yang Menggairahkan. Wahana Informasi dan Komunikasi Pendidikan TK dan SD. Edisi 3.

Rifa'i, A. (2013). Efektifitas Model Pembelajaran Group Investigation Bentuk Co-op Co-op Terhadap Peningkatan Hasil Belajar Siswa SMA. Artikel Penelitian, Program Studi Pendidikan Ekonomi FKIP Universitas Tanjungpura Pontianak. http://jurnal.untan.ac.id/index.php/jpdpb/article/viewFile/3467/3499 (Diakses 25 November 2014).

Rusman (2013). Model-model Pembelajaran: Mengembangkan Profesionalisme Guru. Jakarta: Rajawali Pers.

Saddhono, K., \& St.Y.Slamet (2012). Meningkatkan Keterampilan Berbahasa Indonesia (Teori dan Aplikasi). Bandung: CV. Karya Putra Darwati.

Slavin, R.E. (2010). Cooperative Learning, Teori, Riset, dan Praktik. Terjemahan Narulita Yusron. Bandung: Nusa Media.

Sudijono, A. (2014). Pengantar Statistik Pendidikan. Jakarta: Rajawali Pers.

Suparno \& Mohamad, Y. (2007). Keterampilan Dasar Menulis. Jakarta: Universitas Terbuka.

Tompkins, Gail E. (1990). Teaching Writing: Balancing Process and Product. New York: Macmillan Publishing Company. 